\title{
IMPACT OF BOARD STRUCTURE ON FIRM PERFORMANCE IN THE NIGERIAN MANUFACTURING SECTOR
}

\author{
Rogers A. Akinsokeji \\ Department of Economics, Adeyemi College of Education, Ondo, Nigeria \\ rogersadebayo@yahoo.com
}

\begin{abstract}
In this study, the impact of board structure on firm performance is empirically examined using a large cross section of 50 manufacturing firms in Nigeria and the panel data estimation technique. Both the random and fixed effects methods are adopted to provide robust estimates from the pooled data for the firms over a ten-year period (2005-2014) and the estimations are performed using two measures of firm performance and three measures of board structure. The empirical results from the analysis show that board structure has a significant impact on performance of manufacturing firms in Nigeria. The main source of the impact is through board independence and faintly through board size. However, board composition seems to exert very little effect on firm performance for the sample in the study. Also, firm size is shown to be an essential factor in explaining the general behaviour of firm performance and the pattern of effect that board structure has on firm performance. The effect of size is observed by controlling for it in the performance estimations. The study shows that firm size tends to improve the effect of board structure on performance, apart from EPS. The optimization of board size and composition is desirable for performance especially in a setting like Nigeria with diverse firm characteristics.
\end{abstract}

Keywords: board structure, manufacturing firms, ROA, earnings per share.

JEL classification: G32, L6, L25.

\section{Introduction}

Operations and management of modern business organizations have continued to become broader and more encompassing as more strategic firm advantages are devised. In turn, the conflict between remote shareholders and knowledgeable managers of firms has become prominent in modern organizational theory (van Ees, et al, 2003). These modern business practices bring more attention to corporate governance where the long-run conditions of the firm are situated. Although effective corporate governance has been identified to be critical to all economic transactions especially in emerging and transition economies (Dharwardkar George and Brandes, 2000), market institutional conditions that reduce informational imperfections and facilitate effective monitoring of agents, at varying levels of agency interactions, impinge on the efficiency of investment (Kyereboah-Coleman, 2007). This has again caused issues in corporate governance to assume the centre stage for enhanced corporate performance. However, whether the board characteristics will influence firm performance is still raging and questionable in academic and applied research.

In Nigeria, for instance, many firms have continued to operate effectively in spite of inclement economic conditions and the secret has often been linked with the organizational structure at the corporate management level. In the same vein, crashes that have been observed in many firms (especially financial firms) have often been directly linked with failing corporate governance (Sanda et al, 2008). The germane upshot of these diverse outcomes therefore lies on the patterns and directions of corporate handling of firms in relation to its overall performance. 
The impact of board structure on firm performance has received considerable attention in economic and finance literature in recent years. This increased attention has been motivated by the financial scandals that happened to the financial sectors of most economies in the middle part of last decade that led to significant collapse of the financial markets around the world. Though the financial crises had major impacts on the financial sector, many other sectors of the economy received their fair share. The nature of the crises was such that both financial and market indicators dropped considerably in terms of their levels while performance in terms of value and profitability reached their lowest ebbs (Ogbechie and Adi, 2014). Several authors (e.g., Johnson et al., 2000; Mitton, 2002) present evidence indicating that board structure is of first-order and critical importance in determining firm performance, especially during periods of financial instability. For Francis, Hasan and Wu (2012), effective board structure not only tends to limit 'expropriation by managers' when projected returns drop but could also provide a useful shield against excessive scrutiny of overall corporate governance during periods of crisis. Thus, the board structure is an essential fiber for the operational and governance success of a firm.

Corporate governance as discussed up till now has been shown to demonstrate its influences on firm activities on various facets. It is generally accepted that boards of directors play a fundamental role in corporate governance and that the structure of the board matters (Jensen 1993). However, the board as a factor also comes in more generalized format. For instance, there is no consensus as to what the optimal board structure or composition is (Dalton et al. 1998).

Nigeria, realizing the need to align with the international best practice identifies board composition and operation as the major weakness in the current corporate governance practice in Nigeria. Hence, the release in 2003 of the code of corporate governance in Nigeria by Security and Exchange Commission (SEC) and Corporate Affairs Commission (CAC) was aimed at improving corporate governance in firms operating in the capital market. The Code was further modified and updated in 2008 following the looming crises, especially in the banking and other financial sector participants. The Central Bank of Nigeria (CBN) also released the code of corporate Governance for Bank in Nigeria, in 2006, to accommodate the Post Consolidation era.

Although previous corporate laws in Nigeria attempt at protecting the often-violated shareholders' right, the SEC release on the Conduct of Shareholders Association in Nigeria (2007), more than ever before, was designed to ensure that association member uphold high ethical standard and make positive contribution in ensuring that the affairs of public companies are run in an ethical and transparent manner and in compliance with the code of corporate governance for public companies.

Based on the foregoing, the broad objective of this study is to analyse the dynamic linkages between corporate performance and board structure in the Nigeria manufacturing sector by examining firms listed in the Nigerian Stock Exchange. Specifically, the study aims at analysing the impact of board composition on performance of the Nigerian Manufacturing firms.

\section{The Model and Methodology}

The study examines the impact of board structure on corporate performance. The study derived its theoretical framework from the Principal-Agent Theory of Jensen and Meckling (1976) which investigate the incentives faced by each of the parties and the elements entering into the determination of the equilibrium contractual for characterizing the relationship between the manager (i.e. agent) of the firm and the outside equity holders (i.e. principals) (Jensen \& Meckling, 1976). 
The study adapts a version of Fich and Shivdasani (2004) model which relates firm performance with some indicators of board structure. Thus, implicitly we have:

$$
\mathrm{y}_{j}=\alpha_{k}+\beta_{k} \mathrm{x}_{k}^{\prime}+\mathrm{e}_{j}
$$

Where $y_{j}$ is the dependent variable $j$ representing each of the measures of performance, $\alpha_{k}$ is the constant parameter, $x_{k}^{\prime}$ is the vector of corporate governance measures including board structure with gradient $\beta_{k}$ and $e_{j}$ is the error term in equation $j$. Basically, two measures of board structure are adapted viz a viz: board size and board composition (Coles, et al, 2001; Bhagat and Black, 2000). The study also adopts two measures of corporate performance as entrenched in the literature; they are return on asset and profit margin (Dedman and Lin, 2002; Brickley, Coles and Jarrell, 1997).

Following Fich and Shivdasani (2004) that relate board structure to corporate performance indicators we proceed to present the following empirical models in that relate four measures of corporate performance (ROE, ROA, EPS and PRM) with board structure variables which inform the use of four empirical models in equations 2 and 3.

$\mathrm{ROA}_{\mathrm{it}}=\Omega_{0}+\Omega_{1} \mathrm{BS}_{\mathrm{it}}+\Omega_{2} \mathrm{BCOMP}_{\mathrm{it}}+\Omega_{3} \mathrm{BIND}_{\mathrm{it}}+\Omega_{4} \mathrm{CEO}_{\mathrm{it}}+\Omega_{5} \mathrm{SIZE}_{\mathrm{it}}+\Omega_{6} \mathrm{EPS}_{\mathrm{it}}+\mathrm{U}_{1 \mathrm{t}}$ $E P S_{t}=\lambda_{0}+\lambda_{1} B S_{i t}+\lambda_{2} B C O M P_{i t}+\lambda_{3} B I N D_{i t}+\lambda_{4} C E O_{i t}+\lambda_{5} S I Z E_{i t}+\lambda_{6} E P S_{i t-1}+U_{2 t}$

In the set of models above, returns on assets (ROA) is indicative of the internal efficiency of the firm in terms of operational and managerial activities. These measure shows how the resources of the firm are being put to use as well as the attainment of the basic objective of the firms, namely profit maximization. Earnings per share (EPS) reflects the market performance and the related shareholding benefits accruing from these firms. Indeed, these factors show efficiency of the firms in using shareholders' funds as well as prudence in relating with the owners of the firms.

Board size (BS) is a major indicator of board composition and it reflects the total number of individuals that make up the board for each firm. It has been argued that larger boards tend to inhibit efficiency in decision making as well as attainment of quality decisions for the corporations. Essentially, large boards in our models are expected to have negative impacts on the firm. A caveat in this regard is the fact that a benchmark number has not been presented in this study and hence, the coefficient of the BS variable will be interpreted with caution.

Board composition (BCOMP) shows the ratio of executive to non-executive directors in the board. Due to the technicalities and capabilities involved, it is expected that a board with more executive directors will improve corporate decisions and overall governance mechanism. Hence, a positive relationship is expected between BCOMP and each of the dependent variables. Board independence (BIND) reflects the level of autonomy the board has in relation to the shareholders and the level of autonomy of the various committees of the board. Apparently, more independence of the board is expected to deliver appreciably higher governance effects on the firms and therefore, promote the growth of such firms.

CEO status (CEO) is included to show the status of the Chief Executive in the firm in terms of dual functioning. Recent regulatory propositions have suggested that dual-functioning CEOs tend to undermine or subvert the effectiveness of the board in the companies. These regulations agree that firms that have CEOs as board chairmen do not tend to perform as well as those without such arrangement. Hence CEO status should have a negative coefficient in the regression equations.

All the other variables in the models are control variables. Firm size (SIZE) shows the strength of the firm in terms of asset base and ability to weather unfavourable conditions. Large firms would ideally survive board mismanagement better than small firms. In this regard, firm size is expected to positively affect the performance indicators in the models. In the same vein, debt structure of the firm is expected to have an ambiguous impact on the firm performance depending on the nature of the debt. 
Secondary data for 50 non-financial companies in the Nigerian Stock Exchange (NSE) are employed in the study. The data is sourced from companies' Annual Reports and NSE Fact book for the period 2005-2014.

\section{Empirical Analysis}

\subsection{Measures of Firm Performance}

The summary statistics of the four firm performance measures are reported in Table1 below. Average return on assets (ROA) for the sample period was highest for the conglomerates and foods, beverages and tobacco sub-sectors with rates of 12.2 and 9.7 percent respectively. These are very impressive rates of return on assets for the sub-sectors and they are higher than all the other countries in the sample. Apparently, these two sectors have highly developed operational management capacities that guarantee optimum management of the firms' assets. These two sectors are also similar in characteristics since they both produce highly consumer related goods with high turnover rate since they are needed on a daily basis. Hence, specialization in production ensures better assets management.

In terms of the other performance variables, the conglomerates sector again has the highest profit margin while the food, beverages and tobacco sector has the highest EPS value on average. These sectors have therefore been shown to be very active in terms of performance indicators and they generally indicate that there is better performance among the firms in the sector. It should also be noted that these sectors also have some of the highest number of sampled firms in the study.

A special statistic of interest in this study is the Jarque Berra coefficients in the summary statistics. It shows the degree of normality, and hence the heterogeneity of the data series. Highly heterogenous series are the precursors for panel data estimation techniques. The J-B values for each of the variables in all the sectors are very high and pass the significance test at the 1 percent level. this indicates that the assumption of normality in the data cannot be accepted: the series for the sectors are non-normally distributed. The implication of this is that the series across sectors are heterogenous and would actually require a panel data estimation technique.

Table 4.1: Descriptive Statistics for Measures of Firm Performance

\begin{tabular}{|l|c|c|c|c|c|}
\hline Sector & Variable & Mean & Std & Skew & J-B \\
\hline \multirow{2}{*}{ Agriculture } & ROA & 3.9 & 7.4 & 1.6 & 263.6 \\
\cline { 2 - 6 } & EPS & 0.5 & 1.8 & 1.6 & 50.5 \\
\hline \multirow{2}{*}{ Building materials } & ROA & 9.2 & 10.4 & 2.2 & 372.4 \\
\cline { 2 - 6 } & EPS & 1.2 & 2.6 & 2.3 & 71.4 \\
\hline \multirow{2}{*}{ Chemical, industrials and paint } & ROA & 5.9 & 10.4 & 2.2 & 372.4 \\
\cline { 2 - 6 } & EPS & 0.8 & 2.6 & 2.3 & 71.4 \\
\cline { 2 - 6 } & ROA & 5.1 & 5.7 & 1.2 & 205 \\
\hline \multirow{2}{*}{ Conglomerate } & EPS & 0.7 & 1.4 & 1.3 & 39.3 \\
\hline \multirow{2}{*}{ Construction } & ROA & 12.2 & 13.8 & 2.9 & 493.7 \\
\cline { 2 - 6 } & EPS & 1.1 & 3.4 & 3.1 & 94.6 \\
\hline \multirow{2}{*}{ Food, beverage \& tobacco } & ROA & 8.8 & 10 & 2.1 & 355.6 \\
\cline { 2 - 6 } & EPS & 1.2 & 2.5 & 2.2 & 68.2 \\
\hline \multirow{2}{*}{ Health care } & ROA & 9.7 & 8.4 & 1.8 & 301.2 \\
\cline { 2 - 6 } & EPS & 1.3 & 2.1 & 1.9 & 57.7 \\
\hline \multirow{2}{*}{ Petroleum } & ROA & 7.4 & 8.4 & 1.8 & 301.2 \\
\cline { 2 - 6 } & EPS & 1 & 2.1 & 1.9 & 57.7 \\
\hline \multirow{2}{*}{ Publishing } & ROA & 6.5 & 7.4 & 1.6 & 263.6 \\
\cline { 2 - 6 } & EPS & 0.9 & 1.8 & 1.6 & 50.5 \\
\hline & ROA & 5.7 & 6.4 & 1.4 & 230.1 \\
\cline { 2 - 6 } & EPS & 0.7 & 1.6 & 1.4 & 44.1 \\
\hline
\end{tabular}

Source: Author's computations 


\subsubsection{Measures of Corporate Board Structure}

In terms of the measures of board structure, the summary statistics reported in Table 2 below shows that board size ranges from 5 to 13 members (in line with the stipulations of SEC). The board size on average is higher for the breweries sector and lower in the agricultural sector. The standard deviations among the variables appear to be quite low, suggesting low variability. This also indicates that the board characteristics among the firms seem to be similar. Each of series also has very low skewness, confirming the results that the series are very similar across the firms (or over time) with low variability. The J-B values for the board independence variable are very high and significant for each of the sectors. These results presents the issues of heterogeneity of the data set among the countries in the sample (see Greene, 2003).

Table 2: Descriptive Statics for Measures of Board Structure

\begin{tabular}{|c|c|c|c|c|c|}
\hline Sector & Variable & Mean & Std & Skew & J-B \\
\hline \multirow{3}{*}{ Agriculture } & BS & 5.2 & 1.19 & 0.02 & 0.18 \\
\hline & BCOMP (\%) & 0.74 & 0.66 & 0 & 0.82 \\
\hline & BIND & 0.8 & 0.26 & -0.03 & 20.4 \\
\hline \multirow{3}{*}{ Breweries } & BS & 12.6 & 2.86 & 0.06 & 0.43 \\
\hline & BCOMP (\%) & 0.36 & 1.6 & 0 & 1.98 \\
\hline & BIND & 0.9 & 0.62 & -0.08 & 49.2 \\
\hline \multirow{3}{*}{ Building materials } & BS & 7.1 & 1.6 & 0.03 & 0.24 \\
\hline & BCOMP (\%) & 0.55 & 0.9 & 0 & 1.11 \\
\hline & BIND & 0.7 & 0.35 & -0.05 & 27.6 \\
\hline \multirow{3}{*}{$\begin{array}{l}\text { Chemical, industrials and } \\
\text { paint }\end{array}$} & BS & 5.4 & 1.23 & 0.03 & 0.18 \\
\hline & BCOMP (\%) & 0.73 & 0.69 & 0 & 0.85 \\
\hline & BIND & 0.9 & 0.27 & -0.04 & 21.2 \\
\hline \multirow{3}{*}{ Conglomerate } & BS & 10.2 & 2.32 & 0.05 & 0.35 \\
\hline & BCOMP (\%) & 0.48 & 1.3 & 0 & 1.61 \\
\hline & BIND & 1 & 0.5 & 0.07 & 40 \\
\hline \multirow{3}{*}{ Construction } & BS & 8.7 & 1.98 & 0.04 & 0.29 \\
\hline & BCOMP (\%) & 0.56 & 1.11 & 0 & 1.37 \\
\hline & BIND & 1 & 0.43 & -0.06 & 34 \\
\hline \multirow{3}{*}{ Food, beverage \& tobacco } & $\mathrm{BS}$ & 9.6 & 2.18 & 0.05 & 0.33 \\
\hline & BCOMP (\%) & 0.51 & 1.22 & 0 & 1.51 \\
\hline & BIND & 0.8 & 0.47 & 0.06 & 37.6 \\
\hline \multirow{3}{*}{ Health care } & BS & 7.9 & 1.79 & 0.04 & 0.27 \\
\hline & BCOMP (\%) & 0.79 & 1 & 0 & 1.24 \\
\hline & BIND & 0.9 & 0.39 & -0.05 & 30.8 \\
\hline \multirow{3}{*}{ Petroleum } & BS & 6.5 & 1.49 & 0.03 & 0.22 \\
\hline & BCOMP (\%) & 0.41 & 0.83 & 0 & 1.03 \\
\hline & BIND & 1 & 0.32 & 0.04 & 25.6 \\
\hline \multirow{3}{*}{ Publishing } & BS & 7.3 & 1.65 & 0.03 & 0.25 \\
\hline & BCOMP (\%) & 0.91 & 0.92 & 0 & 1.14 \\
\hline & BIND & 1 & 0.36 & 0.05 & 28.4 \\
\hline
\end{tabular}

Source: Author's computations

\subsection{Impact of Board Structure on Firm Performance}

The first series of estimates relate to the impact of board structure variables on firm performance variables. The panel data estimation strategy adopted in this section presupposes that the biases in the pooled data could either come from cross sectional heterogeneity or time series (periodic) variations. Hence, the Hausman test of heterogeneity 
is initially conducted to determine the best effects model (random or fixed) to be adopted in the analysis. The result of the Hausman test is reported along with each of the estimation tables. The Chi-square statistic values for both equations with size control and without size control are significant. From these results, the statistic provides little evidence against the null hypothesis that there is no misspecification when the random effect model is employed. Hence, the best method to apply is the Random-effect strategy. In this study, we report the both random and fixed effects estimates in order to provide comparison. Moreover, the results are estimated in two variants with one equation controlling for firm size and the other without control. This is to enable the comparison between smaller and larger firms in terms of their corporate performance given different board structure outcomes.

\subsubsection{Impact of Board Structure on Return on Assets}

The result of the impact of board structure on firms' return on assets is reported in Table 3 below. It can be noticed in the results that both for the estimates with size control and without size control, the Random effects results show more relevant information. For the results controlled for size of firm, the diagnostic statistics are quite high and very impressive. The adjusted $R$ squared value of 0.82 indicates that over 82 percent of the systematic variations in ROA among the firms is explained by the explanatory variables. The $F$ value is also high and easily passes the significance test at the 1 percent level.

Table 3: Board Structure and ROA

\begin{tabular}{|c|c|c|c|c|c|c|}
\hline \multirow{2}{*}{$\begin{array}{l}\text { Explanatory } \\
\text { Variable }\end{array}$} & \multicolumn{3}{|c|}{ With Control for Size } & \multicolumn{3}{|c|}{ Without Control for Size } \\
\hline & OLS & $\begin{array}{c}\text { Fixed } \\
\text { Effects }\end{array}$ & $\begin{array}{c}\text { Random } \\
\text { Effects }\end{array}$ & OLS & $\begin{array}{l}\text { Fixed } \\
\text { Effects }\end{array}$ & $\begin{array}{c}\text { Random } \\
\text { Effects }\end{array}$ \\
\hline Constant & -0.42 & $1.77^{\star \star \star}$ & $-0.42^{*}$ & 0.65 & $3.50^{\star *}$ & 0.65 \\
\hline BS & 0.04 & $-0.15^{*}$ & 0.04 & 0.07 & -0.12 & $0.07^{*}$ \\
\hline BCOMP & -0.04 & 0.09 & -0.04 & -0.04 & 0.13 & -0.04 \\
\hline BIND & $0.22^{* *}$ & 0.15 & $0.22^{* *}$ & $0.23^{* *}$ & 0.14 & $0.23^{* *}$ \\
\hline DEBT & $0.10^{\star \star \star}$ & 0.06 & $0.10^{\star \star \star}$ & $0.09^{* \star}$ & 0.08 & $0.09^{\star \star \star}$ \\
\hline SIZE & 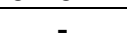 & - & - & $-0.08^{* *}$ & -0.14 & $-0.08^{\star *}$ \\
\hline Lagged Dep & $0.82^{* \star *}$ & $0.27^{\star * *}$ & $0.82^{\star \star \star}$ & $0.79^{\star * \star}$ & $0.27^{* * *}$ & $0.79^{\star * *}$ \\
\hline $\mathrm{R}^{2}$ & 0.76 & 0.86 & 0.76 & 0.76 & 0.84 & 0.76 \\
\hline Adj. $R^{2}$ & 0.75 & 0.82 & 0.75 & 0.75 & 0.82 & 0.75 \\
\hline $\mathrm{F}$ & 110.5 & 34.5 & 110.5 & 129.5 & 34.0 & 129.5 \\
\hline D.W. & 2.39 & 2.06 & 2.39 & 2.42 & 2.08 & 2.42 \\
\hline $\begin{array}{l}\text { Hausman } \\
\text { Test } \\
\text { Summary }\left(x^{2}\right)\end{array}$ & \multicolumn{3}{|c|}{$27.1[0.00]$} & \multicolumn{3}{|c|}{$30.9[0.00]$} \\
\hline
\end{tabular}

Source: Author's computation

The impacts of each of the explanatory variables on ROA are determined by considering the individual coefficients of the explanatory variables in terms of signs and significance. In the results reported, only the coefficient of board composition has a negative sign (which is not in line with apriori expectations) and suggests that larger inside membership in boards could lead to lower returns on assets the firms. The coefficient of BCOMP however fails the significance test at the 5 percent level along with that of board size. These results indicate that neither larger boards nor more inside membership in the boards has any impact on the operational performance of the firm in terms of returns on assets. The coefficient of BIND however passes the significance test at the 5 percent level and is positive. This result demonstrates that board independence has a significant positive impact on firm performance in the Nigerian manufacturing sector. Hence, board independence aimed at 
improving performance is actually not a misguided effort as suggested by Choudhry (2011) in the case of financial firms. Moreover, it has been shown by studies like Levine, (2004), and de Andres, Azofra and Lopez (2005) that board independence is required to discipline management of poorly performing firms, which constitutes a strong merit for board independence has merit.

In terms of the other variable, DEBT passes that significance test at the 1 percent level, thereby indicating that higher leverage in the firms may guarantee better performance in return to assets. The lagged dependent variable is also significant at the 1 percent level. this result indicates that past period performance of the firm tends to affect the current period performance level positively.

The second part of the results show the outcome of the relationship when firm size is not controlled for. This can enable us to discover, in an indirect manner, whether the size of firm has a distributive impact on the behavior of firm performance when board structure variables change (see Greene, 2002). The controlled results also possess impressive goodness of fit statistics, although the adjusted R squared value is lower. However, the random effects estimates show that the result with SIZE report better coefficients estimates than the one without size. Only the coefficient of board composition (with the wrong negative sign) fails the significance test even at the 10 percent level. Board size is significant in the results and it has a positive coefficient, suggesting that larger board size will only deliver performance-enhancing effects on the larger firms. Apparently, the size of the firm would also explain its board membership. Essentially, effectiveness and efficiency may only be guaranteed for larger boards when the firm is sufficiently large. The coefficient of firm size itself however has a negative coefficient and passes the significance test. This shows that larger firms tend to report lower ROA across the sample in the study. The debt and lagged dependent variables are also significant and indicate that debt structure of a firm is a strong determinant of its operational performance and that past performances tend to have distributed effects on current performances of the firms regarding ROA.

\subsubsection{Impact of Board Structure on Earnings per Share}

The last, measure of firm performance in the study is earnings per share (EPS) and the results of the estimates are reported in Table 4 below. For the results controlled for size of firm, the diagnostic statistics are quite high and very impressive. The adjusted $\mathrm{R}$ squared value of 0.73 indicates that over 73 percent of the systematic variations in EPS among the firms is explained by the explanatory variables. The $F$ value is also high at 116.2 and easily passes the significance test at the 1 percent level. This shows the hypothesis of a significant relationship between EPS and all the independent variables combined is significant.

Table 4.7: Impact of Board Structure on Earnings per Share (EPS)

\begin{tabular}{|c|c|c|c|c|c|c|}
\hline \multirow{2}{*}{$\begin{array}{l}\text { Explanatory } \\
\text { Variable }\end{array}$} & \multicolumn{3}{|c|}{ With Control for Size } & \multicolumn{3}{|c|}{ Without Control for Size } \\
\hline & OLS & $\begin{array}{c}\text { Fixed } \\
\text { Effects }\end{array}$ & $\begin{array}{c}\text { Random } \\
\text { Effects }\end{array}$ & OLS & $\begin{array}{c}\text { Fixed } \\
\text { Effects }\end{array}$ & $\begin{array}{c}\text { Random } \\
\text { Effects }\end{array}$ \\
\hline Constant & $0.41^{*}$ & $2.12^{\star \star *}$ & $0.41^{*}$ & 0.73 & 1.21 & 0.73 \\
\hline BS & $0.07^{\star *}$ & 0.10 & $0.07^{* *}$ & $0.08^{\star *}$ & 0.09 & $0.08^{\star \star}$ \\
\hline BCOMP & -0.07 & -0.02 & -0.07 & -0.07 & -0.04 & -0.07 \\
\hline BIND & -0.06 & -0.13 & -0.06 & -0.06 & -0.13 & -0.06 \\
\hline DEBT & $0.06^{*}$ & -0.09 & $0.06^{* *}$ & $0.05^{*}$ & $-0.10^{\star *}$ & $0.05^{*}$ \\
\hline SIZE & & & & -0.02 & 0.07 & -0.02 \\
\hline Lagged Dep & $0.77^{\star * \star}$ & $0.37^{\star * \star}$ & $0.77^{\star \star \star}$ & $0.77^{\star \star \star}$ & $0.37^{\star \star \star}$ & $0.77^{\star \star \star}$ \\
\hline $\mathrm{R} 2$ & 0.73 & 0.81 & 0.73 & 0.74 & 0.81 & 0.74 \\
\hline
\end{tabular}




\begin{tabular}{|l|c|c|c|c|c|c|}
\hline \multirow{2}{*}{$\begin{array}{l}\text { Explanatory } \\
\text { Variable }\end{array}$} & \multicolumn{3}{|c|}{ With Control for Size } & \multicolumn{3}{c|}{ Without Control for Size } \\
\cline { 2 - 7 } & OLS & $\begin{array}{c}\text { Fixed } \\
\text { Effects }\end{array}$ & $\begin{array}{c}\text { Random } \\
\text { Effects }\end{array}$ & OLS & $\begin{array}{c}\text { Fixed } \\
\text { Effects }\end{array}$ & $\begin{array}{c}\text { Random } \\
\text { Effects }\end{array}$ \\
\hline Adj. R2 & 0.73 & 0.78 & 0.73 & 0.73 & 0.78 & 0.73 \\
\hline F & 28.80 & 28.8 & 116.2 & 96.7 & 27.8 & 96.7 \\
\hline $\begin{array}{l}\text { Hausman } \\
\text { Test } \\
\text { Summary }\end{array}$ & \multicolumn{3}{|c|}{$19.7[0.01]$} & \multicolumn{3}{|c|}{$23.2[0.00]$} \\
\hline
\end{tabular}

Source: Author's computation

In terms of the particular contribution of each of the explanatory variables to changes in EPS, only the coefficient of board size has the expected positive sign and is significant at the 5 percent level. This indicates that the size of boards is an essential factor in the determination of the market performance of manufacturing firms. Perhaps larger firms ensure more confidence by stock market investors on the firm's shares and so tends to improve its performance in the market. Indeed, none of the other board structure variables has a significant effect on EPS from the results reported in Table 4.7 below. Thus, larger boards may actually improve firm market performance among manufacturing firms. The coefficient of DEBT and lagged dependent variable also pass the significance test, indicating that debt structure is a very potent instrument in driving EPS or market performance of these firms.

The results for the non-controlled estimates are very similar to that of the size-controlled estimates. Thus, it can be seen that the SIZE coefficient fails the significance test and indicates that size is not a remarkable factor in the relationship between board structure and firm's market performance. In other words, larger or smaller firms do not have significant impact on how a firm's stock performs in the stock market. The coefficients in the estimates are just like those of the results with size control, suggesting that across firms, the size of boards is the main factor that drives earnings per share.

\section{Conclusion and Recommendations}

In this study, the impact of board structure on firm performance was empirically examined using a large cross section of 50 manufacturing firms in Nigeria. It was argued in the study that board size matters for adequate firm growth and overall performance. The panel data estimation technique was employed on the pooled data for the firms over a ten-year period (2005-2014) and estimation was performed using two measures of firm performance and three measures of board structure. The empirical results from the analysis show that board structure has a significant impact on performance of manufacturing firms in Nigeria. The main source of the impact is through board independence and faintly through board size. This implies that independent boards are the most important board structure variable in explaining firm performance for the Nigerian firms. when the board is independent from the management, governance decisions are often made from highly impartial perspectives, with the welfare of shareholders as the optimum motivating factor. In terms of size, the results suggest that smaller boards appear to be more efficient than larger ones, especially when such boards have more autonomy. For many firms in Nigeria, large boards generally imply large budgets for maintenance with rather high cost of ego clashes. This can effectively reduce the role of the board in the agency activity of corporate existence.

The results also show that board composition appears to exert very little effect on firm performance for the sample in the study. Apparently, it does matter much who is in the board, as long as the decisions of the board are binding in the firm. In particular, the proportion of internal and external members in the board does not enhance or inhibit its 
overall performance. Also, firm size was shown to be an essential factor in explaining the general behaviour of firm performance and also the pattern of effect that board structure has on firm performance. The effect of size was observed by controlling for it in the performance estimations. The analyses clearly showed that firm size tends to improve the effect of board structure on performance, apart from EPS.

A number of measures designed to strengthen the infrastructure of corporate governance as a tool for improved firm performance are noted. First, there should be correct board representation among corporate firms in Nigeria. The optimization of board size and composition is desirable for performance especially in a setting like Nigeria with weak takeover market. The board size of companies should be big enough to display a good spread of monitoring skills of the board and enhance its effectiveness. However, it should be small enough to allow quality communication within the board. Also, arising from the point noted above, manufacturing firms should strive at incorporating governance measures that are value-enhancing. Furthermore, there is no gainsaying from the analysis that there is a clear case for board independence since a clear positive relation between board independence and future operating performance of corporate firms have been established in the study.

Finally, this study mentions issues of board efficiency in passing. In this regard, future research could seek to establish methods to test the efficiency mechanisms of board of directors, or how to build a model of effective board structure and establish mechanism of corporate governance. This would go beyond just limiting to testing correlation between them. Furthermore, the study finds that board size matters in its effectiveness. Thus, there appears to be a particular range of board size beyond which its role as a performance enhancement factor begins to wane. There is need for further research to ascertain in empirical terms the boarders in this regard.

\section{References}

Adams, R., D. Ferreira. 2009. Women in the boardroom and their impact on governance and performance. Journal of Financial Economics, 94, pp. 291-309.

Bhagat, S., and B. Black. 2000. Board Independence and Long-Term Firm Performance. Unpublished paper, University of Colorado.

Brickley, J.A., J.L.Coles, and G.Jarrell. 1997. Leadership structure: Separating the CEO and Chairman of the Board, Journal of Corporate Finance, 3, pp. $189-220$.

Choudhry, M. 2011. Effective bank corporate governance: observations from the market crash and recommendations for policy. Journal of Applied Finance \& Banking, 1(1), pp. 179-211.

Coles, J.W., V.B. McWilliams, and N. Sen. 2001. An Examination of the Relationship of Governance Mechanisms to Performance. Journal of Management, 27 (1), pp. 23 - 50.

Dalton, D.R., C.M. Daily, A.E. Ellstrand, and J.L. Johnson. 1998. Meta-Analytic Reviews of Board Composition, Leadership Structure, and Financial Performance. Strategic Management Journal, 19, 269-290.

de Andres, P. A., V. Azofra, and F. Lopez. 2005. Corporate boards in OECD Countries: Size, composition, functioning and effectiveness. Corporate Governance, 13, 197-210.

Dedman, E., and S. W. J. Lin. 2002. Shareholder wealth effects of CEO departures: Evidence from the UK. Journal of Corporate Finance, 8 (1), pp. $81-104$.

Dharwardkar, R, George, G and Brandes, P (2000): "Privatization in Emerging Economies: An Agency Perspective", Academy of Management Review, 25(3), pp. 650-669

Fama, E. and M. Jensen. 1983. Separation of Ownership and Control. Journal of Law and Economics, 26(2), pp. 302-325.

Eliezer M. Fich and Anil Shivdasani. 2005. The Impact of Stock-Option Compensation for Outside Directors on Firm Value. The Journal of Business, 78(6), 2229-2254. 
Greene, W.H. 2003. Econometric Analysis (5th Ed). Prentice Hall, New Jersey, USA.

Gujarati, D.N. 2004. Basic Econometrics, Fourth Edition. The McGraw-Hill Companies, New York, USA.

Jensen, M. and W. Meckling. 1976. Theory of the Firm: Managerial Behaviour, Agency Costs and Ownership Structure. Journal of Financial Economics, 3, pp. 305-360

Jensen, M. C. 1993. The Modern Industrial Revolution, Exit, and the Failure of Internal Control Systems. Journal of Finance, 48(3), pp. 832-880

Johnson, S., P. Boone, A. Breach, E. Friedman. 2000. Corporate governance in the Asian financial crisis. Journal of Financial Economics, 58, pp. 141-186.

Kyereboah-Coleman, A. 2007. Corporate Governance and Firm Performance in Africa: A Dynamic Panel Data Analysis. A Paper Prepared for the "International Conference on Corporate Governance in Emerging Markets" Organized by the Global Corporate Governance Forum (GCGF) and Asian Institute of Corporate Governance (AICG). 15th -17th November, 2007, Sabanci University, Istanbul, Turkey

Mitton, T. 2002. A cross-firm analysis of the impact of corporate governance on the East Asian financial crisis. Journal of Financial Economics, 64, pp. 215-241.

Ogbechie, C. and B. Adi. 2014. Exploring Board Size and Firm Performance: 'Is there a Kuznets' Curve Relationship? Evidence from Nigeria. International Journal of Business and General Management, 3(1), pp. 9-30.

Sanda, A.U., Garba, T. and Mikail, A.S. 2008. Board Independence and Firm Financial Performance: Evidence from Nigeria. A Paper Submitted to the Centre for the Study of African Economies (CSAE) for presentation at the CSAE Conference 2008 titled Economic Development in Africa at St Catherine's College, University of Oxford, Oxford, 16-18 March. van Ees, H., Postma, T.J.B.M. and Sterken, E. 2003. Board Characteristics and Corporate Performance in the Metherlands. Eastern Economic Journal, 29(1) pp. 41-58.

\section{Bio-note}

Rogers Adebayo Akinsokeji, Ph.D. is a lecturer at the department of Economics, Adeyemi College of Education, Ondo. His areas of research interest are industrial economics, economics of production, and statistics. 